\title{
DESIGN ESCANDINAVO NO BRASIL (1955-1976): A DIVULGAÇÃO ATRAVÉS DE EXPOSIÇÕES
}

\author{
Larissa Guelfi Soares \\ Escola Superior de Propaganda e Marketing (ESPM-SP) \\ lari.guelfi@outlook.com \\ Patrícia Amorim, Profa. Dra. \\ Escola Superior de Propaganda e Marketing (ESPM-SP) \\ pat.amorim@gmail.com
}

Resumo: A presente pesquisa ainda em desenvolvimento possui como tema a divulgação do design escandinavo moderno - que compreende a produção dos países Dinamarca, Suécia, Noruega e Finlândia - no Brasil, no período de 1955 a 1976, por meio de exposições realizadas no país. Para tal, foram adotadas tanto a abordagem quantitativa quanto a qualitativa. O método de pesquisa escolhido de forma a englobar ambas as abordagens foi o método dialético. A metodologia de procedimento é de caráter histórico e as técnicas de pesquisa utilizadas foram bibliográfica e documental. Dessas, as fontes de coleta de dados empregadas foram, respectivamente, livros, artigos científicos e imprensa escrita (jornais e revistas), e documentos de arquivos de acervos de bibliotecas de museus, materiais gráficos, fotografias e cartas. Para a coleta dos dados referentes à pesquisa documental, foram realizadas visitas a acervos de bibliotecas de museus no estado de São Paulo, o Museu de Arte de São Paulo (MASP) e o Museu de Arte Moderna de São Paulo (MAM-SP), dado que essas instituições sediaram os eventos estudados. Fazendo uso dessas estratégias metodológicas, foram identificas características do design escandinavo moderno - que tanto o aproximam do funcionalismo vigente quanto o diferenciam das demais vertentes dessa tendência - e o contexto histórico internacional e nacional no qual esse se desenvolveu e foi difundido. Também por meio de tais estratégias, foi realizado o mapeamento das exposições ocorridas no Brasil no período determinado e estabelecido um panorama da proporção e da localização desses eventos. O primeiro desses foi a Exposição de Arte Decorativa Finlandesa que ocorreu no final de 1958 e início de 1959 no Museu de Arte Moderna do Rio de Janeiro (MAM-RJ) e no MASP. No ano de 1965, foi realizada a Exposição de Desenho Industrial Sueco, no Rio de Janeiro e São Paulo. Houve também a presença de produtos escandinavos na II Bienal de Desenho Industrial, no MAM-RJ, em 1970, os quais foram posteriormente também apresentados em exposições em Brasília e em São Paulo. Outra mostra identificada foi a presença de produtos finlandeses na XII Bienal de São Paulo, em 1973. Por fim, houve a mostra Desenho Industrial Finlandês, de 1976, 
organizada no MASP. Desses eventos, constatou-se a preeminência da exposição ocorrida entre 1970 e 1971, posto que tal exposição ocorreu em três cidades brasileiras e possui maior volume de registro em acervo. Em virtude disso, as pecas gráficas utilizadas nesse evento e identificadas pela pesquisa documental estão sendo analisadas quanto a seu conteúdo para a finalização da pesquisa. Uma vez que dados dessa natureza são escassos na historiografia do design brasileiro, os resultados obtidos pelo desenvolvimento parcial da pesquisa contribuem aos estudos acerca da historia do design brasileiro e seu contato com produções internacionais.

Palavras-chave: design escandinavo, funcionalismo, exposições, museus 